\title{
KONSEP MARKETING MIX SYARIAH
}

\author{
Patah Abdul Syukur dan Fahmi Syahbudin ${ }^{1,2}$ \\ ${ }^{1,2}$ Afiliasi: Sekolah Tinggi Ekonomi Islam SEBI. Email: fabdoels@gmail.com
}

\begin{abstract}
ABSTRAK. Pokok permasalahan yang akan dibahas dalam penulisan ini adalah konsep marketing mix yang sesuai dengan syariah. Penilaian konsep marketing mix yang sesuai syariah ini menilai variabel Product (Produk), Price (Harga), Place (Penempatan), dan Promotion (Promosi) dengan aturan-aturan muamalah dalam islam. Tujuan dari penelitian ini adalah untuk mengetahui dan menjelaskan konsep marketing mix syariah, serta sebagai kontribusi keilmuan berkaitan dengan marketing mix syariah. Teori yang digunakan dalam penelitian ini yaitu teori marketing, marketing mix, serta teori tentang muamalah yang sesuai dengan syariah. Penelitian ini memfokuskan pada penilaian marketing mix dengan aturan-aturan muamalah dalam islam. Metode yang digunakan dalam penelitian ini adalah kajian pustaka baik bersumber data buku ataupun jurnal, sedangkan untuk aspek penilaiannya yaitu ditinjau dari Al-Qur'an, Hadits, Ijtihad para ulama, dan karya ilmiah yang berkaitan dengan penelitian. Penelitian ini menghasilkan konsep marketing mix yang sesuai dengan syariah meliputi variabel Product (Produk), Price (Harga), Place (Penempatan), dan Promotion (Promosi) yang telah disesuaikan dengan aturan-aturan dalam muamalah islam, penelitian ini juga sebagai saran bagi para pelaku bisnis yang ingin menjalankan bisnisnya sesuai syariat Islam. Sehingga konsep marketing mix syariah ini memiliki perbedaan dengan marketing mix pada umumnya karena telah disesuaikan dengan aturan muamalah dalam islam.
\end{abstract}

Kata kunci: marketing, marketing mix, marketing mix syariah

ABSTRACT. The main issues will be discussed in writing this is how the concept of marketing mix according to sharia. Assessment the concept of marketing mix appropriate sharia this assess variable product, price, place, and promotion into rules muamalah in Islam. The purpose of this study is to find and explain the sharia marketing mix, and as a contribution scientific pertaining to sharia marketing mix. A theory that used in this research that is the theory marketing, marketing mix, and a theory about muamalah in accordance with sharia. Methods used in this research is a literature study good sourced data book or journal, while on the aspect of this assessment that is in terms of the Al-Qur'an, Hadith, ijtihad ulama, and the work of scientific relating to the study. This research come up with concepts marketing mix according to sharia covering variable product, price, place, and promotion that has been adjusted for rules in Islamic him, the research also as a suggestion for actors businesses that would like to run business in accordance Islamic sharia. So that the concept of sharia marketing mix it has different to marketing mix in general because has been adjusted for rules him in Islam.

Keywords: marketing, marketing mix, sharia marketing mix

\section{PENDAHULUAN}

Kehidupan manusia tak lepas dari kegiatan ekonomi, hal ini tak bisa terpisahkan karena dari sifat manusia yang saling membutuhkan. Dalam 
perkembangan perekonomian manusia, transaksi jual beli semakin kompleks sehingga banyak lahir ilmu-ilmu yang berkaitan dengan transaksi ekonomi salah satunya yaitu ilmu marketing. Menurut Kotler, Kartajaya, \& Setiawan (2010), "Ilmu marketing hadir sebagai respon dari pasca revolusi industri dimulai, lebih tepatnya saat perkembangan teknologi produksi selama revolusi industri," (hal. 5).

Dalam perkembangannya, ilmu marketing awalnya bersifat productcentric. Seiring berjalannya waktu, marketing berubah menjadi customer oriented, dimana marketing pada masa ini pemasar berusaha menarik konsumen dengan memahami segala kebutuhan konsumen. Setelah tren marketing customer oriented berlalu, marketing bukan hanya menjadikan orang sebagai konsumen, namun juga memandang mereka (para konsumen) sebagai manusia seutuhnya yang memiliki pikiran, hati dan spirit (Kotler, Kartajaya, \& Setiawan, 2010, hal. 3-5).

Marketing mempunyai peranan yang cukup penting dalam kegiatan perekonomian terutama bagi perusahaan, karena marketing berperan sebagai langkah menjual produk yang dimilikinya kepada konsumen dan menjalankan tujuan utama perusahaan.

Marketing memiliki peranan penting bagi perusahaan, menurut sebuah survei tentang 10 tantangan besar yang dihadapi para Chief Executive Officer (CEO) pada tahun 2006, mengungkapkan bahwa pada peringkat 5 besar ada "pertumbuhan pendapatan yang stabil dan berkelanjutan" dan "loyalitas/retensi pelanggan". Pencapaian kedua hal tersebut sangat bergantung pada marketing. Para CEO juga mengetahui pentingnya marketing untuk membangun merek dan basis pelanggan yang loyal, yang merupakan aset tak berwujud yang membentuk presentase nilai yang besar dari sebuah perusahaan, (Kotler \& Keller, 2009, hal. 4).

Dari hasil survei diatas, marketing bukan hanya sekedar transaksi jual beli semata, tapi juga kegiatan interaksi antara konsumen dan produsen yang bisa menghasilkan kesepakatan jual beli. Marketing erat kaitannya dengan strategi dalam kegiatan bisnis dalam upaya mencapai tujuan perusahaan yaitu memaksimalkan keuntungan, selain itu juga marketing berfungsi untuk menciptakan konsumen yang loyal. Sehingga ketika terjadi persaingan usaha, konsumen tidak terpengaruh oleh produk pesaing.

Dalam upaya mencapai tujuan perusahaan meningkatkan pendapatan dan meraih pelanggan, perlu strategi yang tepat dalam merengkuh konsumen. Dalam ilmu marketing salah satu aplikasi strategi yang berkenaan dengan hal tersebut adalah melakukan marketing mix (bauran marketing). Strategi marketing mix ini seringkali digunakan oleh perusahaan-perusahaan dalam mencapai tujuan pemaksimalan laba perusahaan.

Faktor penggunaan marketing mix oleh perusahaan ini tak terlepas dari perubahan sosial di masyarakat yang selalu dinamis. "Hal ini disebabkan munculnya teknologi internet dan globalisasi," (Kotler, Kartajaya, \& Setiawan, 2010, hal. 5). Sehingga selera masyarakat yang selalu berubah setiap waktunya dan juga pergantian dari abad teknologi menuju abad 
Jurnal Ekonomi dan Perbankan Syariah

Vol. 4. No.1, April 2017: 71-94, ISSN (cet): 2355-1755 | ISSN (online): 2579-6437

| 73

informasi yang membuat sehingga penerapan marketing harus melibatkan berbagai unsur.

Menurut Tjiptono (2004) "Konsep marketing mix yang diperkenalkan terdiri dari beberapa unsur, meliputi product (produk), price (harga), place (tempat), dan promotion (promosi)," (hal.30). Namun dalam penetapan strategi marketing mix ini setiap unsur-unsur harus di perhatikan, karena seringkali muncul masalah dari empat unsur variabel tersebut. Dari segi produk, banyaknya perusahaan yang menciptakan produk dan persaingan produk seringkali diterpa isu-isu yang tidak mengenakkan diantaranya produk yang terkontaminasi zat berbahaya. "Produk-produk berbahaya kini beredar luas di masyarakat, hal ini dikarenakan orientasi ekonomi yang dilakukan oleh produsen untuk mengeruk keuntungan secara instan," (Setiawan, 2015). Selain itu juga masalah lain yaitu, masalah produk non halal yang meresahkan umat Muslim sehingga membuat Pemerintah mengeluarkan Undang-Undang Jaminan Produk Halal pada tahun 2014.

Dari segi price, masalah yang sering muncul adalah terkait harga yang terkadang dikeluhkan konsumen atau bahkan merugikan konsumen. Contohnya berita yang bersumber dari portal berita online Merdeka yaitu

Kasus getok harga sekali makan habis satu juta menimpa seorang konsumen ketika makan di salah satu restoran daerah anyer pada September 2014, kasus tersebut menyeruak saat konsumen tersebut mengunggah apa yang terjadi pada dirinya ke media sosial, dimana saat selesai makan ketika menerima kwitansi pembayaran terkejut dan harus membayar makanan yang dibelinya seharga satu juta rupiah, dengan rincian Dua ikan bakar dihargai $\mathrm{Rp} 400.000,1$ cumi saos tiram $\mathrm{Rp}$ 180.000, 3 cah kangkung Rp 200.000, 1 baso sapi Rp 20.000, 2 nasi putih Rp 90.000, 2 lalap dan sambal Rp 30.000, dan 1 es teh manis Rp 80.000. Sehingga jumlah total yang harus dibayar oleh pemesan adalah Rp 1.000.000, (Merdeka, 2014).

Selain itu pula persaingan harga antar perusahaan menjadi salah satu polemik yang terjadi dalam persaingan usaha. Perang harga menjadi fenomena tersendiri dalam persaingan usaha, salah satunya perang harga dalam tarif telekomunikasi seluler.

Perang tarif telekomunikasi seluler pernah dilakukan Mentari dan XL pada tahun 2008. Provider seluler Mentari menyatakan harga produknya paling murah dibandingkan dengan operator lain, karena tarif produknya Rp. 0.-. Provider seluler XL tidak mau kalah dengan produk yang diluncurkan oleh Provider Mentari dalam penetapan tarif produknya dan menyindir iklan Mentari dengan slogan iklan "Tong kosong nyaring bunyinya. Hati-hati janji si nol!", (Adona, 2012, hal. 58).

Segi place juga bukan tanpa masalah, dalam place ini berkaitan dengan pemilihan lokasi yang tepat bagi perusahaan untuk memasarkan produknya, lalu dalam saluran distribusi tidak lepas dari isu-isu tentang penimbunan, hal yang sering dijumpai adalah penimbunan kebutuhan masyarakat seperti bahan pokok, diduga spekulan memiliki peranan dalam 
kegiatan penimbunan ini, salah satu contoh kasus di masyarakat terkait hal ini dikutip dari portal berita online Batam Pos yaitu pada kasus penimbunan yang terjadi pada akhir Oktober 2015 di Batam

Ketua Kamar Dagang dan Industri (Kadin) Kepri, Makruf Maulana, mengatakan kelangkaan dan mahalnya harga beras di Batam diduga karena permainan para kartel atau kelompok usaha yang ingin mengendalikan harga komoditas tersebut. Tujuannya, mengeruk untung berlipat saat harga kebutuhan pokok itu meroket. "Ini jelas dikendalikan oleh kartel-kartel tertentu," ujar Makruf, Rabu (21/10). Menurut Makruf, kecurigaan itu berdasar. Pasalnya, beberapa waktu lalu pihaknya mengaku mendapat laporan stok beras di Batam untuk beberapa bulan ke depan masih cukup, (Batam Pos, 2015).

Segi promotion, masalah yang dihadapi adalah bentuk iklan yang berlebih-lebihan, menjelek-jelekkan produk pesaing, iklan yang mengandung kebohongan kepada khalayak publik, dan juga iklan melanggar norma kesopanan. Salah satu contohnya iklan Mie Sedap yang bermasalah pada tahun 2011 .

Pada 28 Desember 2011 badan regulator Komisi Penyiaran Indonesia (KPI) menegur semua stasiun televisi untuk memperbaiki adegan dalam tayangan iklan Mie Sedaap. Iklan tersebut menayangkan adegan seorang guru yang memegang sebuah produk mie dan di kepalanya bertengger seekor ayam. Menurut KPI, tayangan iklan tersebut tidak memperhatikan norma dan nilai yang berlaku dalam lingkungan sekolah, memperolok tenaga pendidik (guru) dan merendahkan sekolah sebagai lembaga pendidikan, (Adona, 2012, hal. 46).

Islam adalah agama rahmatan lil alamin, karena Islam mengatur segala aspek kehidupan, tidak hanya terfokus pada aspek ibadah yang berhubungan secara vertikal antara yang menggambarkan hubungan manusia dan Allah saja, tapi juga aspek muamalah yang erat kaitannya dengan hubungan antar sesama manusia termasuk kegiatan ekonomi di dalamnya.

Segala aspek muamalah asal hukumnya boleh kecuali jika ada dalil yang mengharamkannya, hal ini mengacu pada kaidah fiqih "Al ashlu fil muamalah al ibahah, illa ayyadulladdaliilu 'ala tahrimihi". Islam membebaskan manusia untuk bermuamalah selama tidak melanggar syariat. Aturan muamalah Islam merupakan rambu-rambu bagi setiap muslim dalam melakukan transaksi ekonomi, karena acuan muamalah Islam ini berasal dari Al-Quran dan As-Sunnah, selain itu juga ijtihad para ulama tentang muamalah bisa menjadi rujukan bagi seluruh muslim dalam menjalankan kegiatan muamalah seperti dalam kegiatan ekonomi.

Poin-poin penting dari muamalah Islam ini adalah melarang segala bentuk transaksi bathil yang bisa menimbulkan mudharat bagi orang lain seperti transaksi riba, penipuan dan sebagainya. Selain itu juga transaksi yang dilakukan harus jelas dan suka rela baik itu penjual maupun pembeli.

Firman Allah swt: 
Jurnal Ekonomi dan Perbankan Syariah

Vol. 4. No.1, April 2017: 71-94, ISSN (cet): 2355-1755 | ISSN (online): 2579-6437

| 75

Artinya: "Hai orang-orang yang beriman, janganlah kalian memakan harta sesamamu secara bathil, kecuali dengan melalui transaksi jual beli secara suka rela diantara kalian," (Q.S. An-Nisa: 29).

Marketing mix merupakan bagian dari ilmu marketing. Marketing bisa diartikan sebagai suatu kegiatan sosial ekonomi, kegiatan sosial ekonomi juga tak lepas dari aturan Islam, jauh sebelum munculnya teori ilmu marketing di zaman modern, Rasulullah telah mengajarkan marketing yang baik melalui akhlak beliau yang mulia. kesuksesan beliau dalam berdagang layak menjadi referensi bagi marketer dalam memasarkan produknya.

Para Ulama-ulama Islam pada setiap zamannya juga banyak yang menyampaikan ijtihadnya tentang muamalah Islam dan terkadang secara tidak langsung juga membahas tentang marketing syariah seperti pendapat Imam Al-Ghazali yang mengemukakan teori prinsip untung sedikit, penjualan banyak yang menjadi salah satu terobosan ekonomi modern, (Bashri,2007,hal. 131).

\section{TELAAH TEORITIS}

\subsection{MARKETING}

Marketing merupakan salah satu cabang ilmu dalam ekonomi, ilmu marketing hadir sebagai jawaban dari permasalahan kebutuhan manusia yang dinamis, hal ini menjadi kebutuhan perusahaan untuk meraih pelanggan melalui strategi pemasaran produk yang tepat.

Menurut Kotler \& Amstrong (1997), "Marketing merupakan suatu proses sosial dan manajerial yang membuat individu dan kelompok memperoleh apa yang mereka butuhkan serta inginkan lewat penciptaan dan pertukaran timbal balik produk dan nilai dengan orang lain," (hal. 6).

Dari pendapat Kotler \& Amstrong diatas, dapat diketahui bahwa marketing merupakan proses kegiatan sosial yang berhubungan dengan kegiatan penciptaan dan pertukaran produk dan nilai dengan orang lain (masyarakat/konsumen).

Menurut Kotler \& Amstrong (1997), "Fungsi marketing pada umumnya, yaitu melakukan penjualan produk dan juga memuaskan kebutuhan pelanggan," (hal. 5). Seiring perkembangan zaman fungsi marketing menjadi lebih dinamis, menurut Kotler \& Keller (2009), "Marketing menjadi begitu penting karena untuk membangun merek dan juga membangun loyalitas pelanggan," (hal. 4).

Maka dari beberapa pendapat tersebut dapat diketahui bahwa fungsi marketing adalah:

1. Sarana untuk menjual produk kepada konsumen

2. Memuaskan pelayanan dalam penjualan produk kepada konsumen.

3. Mengkomunikasikan nilai-nilai perusahaan.

4. Membangun citra perusahaan di masyarakat 
5. Membangun branding di masyarakat.

6. Menciptakan pelanggan yang loyal kepada perusahaan.

\subsection{MARKETING MIX}

Menurut Stanton (1991), “Marketing mix merupakan kombinasi dari empat variabel dari kegiatan inti dalam sistem pemasaran yang meliputi produk, tingkat harga, promosi dan juga sistem distribusi," (hal. 78). Sedangkan Tjiptono (2004) Menyatakan, "Marketing mix sebagai seperangkat alat yang dapat digunakan pemasar untuk membentuk karakteristik barang atau jasa yang ditawarkan kepada pelanggan," (hal. 30).

Berdasarkan definisi para ahli diatas dapat disimpulkan bahwa marketing mix adalah penggunaan beberapa unsur variabel pemasaran yang berbeda untuk bisa meraih dan mempengaruhi konsumen secara lebih efektif dan tepat sasaran.

Menurut Tjiptono (2004) "Konsep marketing mix yang diperkenalkan terdiri dari beberapa unsur, meliputi Product (produk), Price (harga), place (tempat), dan promotion (promosi)," (hal.30).

Dari penjabaran di atas, dapat diketahui bahwa marketing mix terdiri dari beberapa unsur baik segi produk, harga, tempat (penempatan), maupun promosi. Secara rincinya sebagai berikut:

\subsubsection{Products (Produk)}

Menurut Kotler \& Amstrong (1997), "Produk Sebagai segala sesuatu yang dapat ditawarkan ke pasar untuk mendapatkan perhatian, dibeli, dipergunakan atau dikonsumsi dan yang dapat memuaskan keinginan atau kebutuhan," (hal. 274). Dari definisi tersebut dapat diketahui produk adalah sesuatu yang dihasilkan atau dibuat untuk dipasarkan kepada konsumen untuk digunakan ataupun untuk dikonsumsi agar memenuhi kebutuhannya.

Kotler \& Amstrong (1997) menambahkan, Komponen dan langkahlangkah untuk melakukan strategi bauran produk meliputi:

1. Atribut produk, terdiri dari beberapa unsur yang membentuk atribut produk yaitu:

a. Mutu produk, berupa kemampuan produk untuk melaksanakan fungsinya. termasuk didalamnya keawetan, keandalan, ketepatan, kemudahan dipergunakan dan diperbaiki serta atribut lainnya yang berkaitan dengan mutu.

b. Sifat produk, yaitu alat bersaing untuk membedakan produk perusahaan dengan dengan perusahan lainnya (diferensiasi produk) seperti ciri khas suatu produk. rancangan produk, yaitu rancangan konsep yang bukan sekedar menguraikan tampilan produk, namun juga terkait dengan inti sebuah produk.

2. Penetapan merek, merek merupakan nama, istilah, tanda ataupun rancangan yang bertujuan sebagai pengenal suatu produk kepada konsumen dan pembeda dari produk pesaing. Dalam merancang 
Jurnal Ekonomi dan Perbankan Syariah

Vol. 4. No.1, April 2017: 71-94, ISSN (cet): 2355-1755 | ISSN (online): 2579-6437

produk, perusahaan harus menetapkan merek yang tepat agar bisa menarik konsumen untuk membeli produk serta menimbulkan kesan di benak konsumen.

3. Pengemasan, yaitu aktivitas merancang dan membuat wadah atau pembungkus suatu produk. Pengemasan bertujuan untuk melindungi produk itu sendiri, dengan adanya pengemasan produk akan membuat produk terlihat menarik.

4. Pembuatan label, label mempunyai fungsi sebagai identifikasi produk atau merek, mengklasifikasi produk, bersifat menguraikan beberapa hal mengenai produk serta label berfungsi untuk mempromosikan produk dengan gambar menarik.

5. Pelayanan pendukung produk, merupakan penambahan pada produk aktual, (hal. 278-298).

\subsubsection{Price (Harga)}

Price (harga) merupakan salah satu unsur marketing mix. "Harga didefinisikan sebagai jumlah uang yang ditagihkan untuk suatu produk atau jasa. Lebih luasnya yaitu jumlah dari nilai yang dipertukarkan konsumen untuk manfaat memiliki atau menggunakan produk atau jasa," (Kotler \& Amstrong, 1997, hal. 340).

Secara umum menurut Kotler \& Amstrong (1997), penetapan harga dibagi menjadi dua macam:

1. Penetapan harga berdasarkan biaya,terbagi menjadi beberapa macam:

a. Penetapan harga cost plus, yaitu penetapan harga dengan menambahkan angka standar pada biaya produk.

b. Penetapan harga titik impas (penetapan harga dengan laba sasaran), yaitu penetapan harga impas dengan biaya membuat dan memasarkan produk ataupun penetapan harga untuk menghasilkan laba sasaran.

c. Penetapan harga berdasarkan nilai, yaitu menetapkan harga berdasarkan pada persepsi pembeli mengenai nilai dan bukan pada biaya penjual.

2. Penetapan harga berdasarkan persaingan, terbagi menjadi dua macam:

3. Penetapan harga menurut keadaan, yaitu penetapan harga dengan mengikuti harga kompetitor bukan dari faktor internal perusahaan.

4. Penetapan harga penawaran penutup, yaitu penetapan harga berdasarkan pendapat perusahaan mengenai bagaimana cara menetapkan harga pesaing, hal ini dipergunakan bila perusahaan mengikuti lelang untuk memperoleh pekerjaan, (hal. 351). 


\subsubsection{Place (Penempatan)}

Place merupakan unsur lainnya yang digunakan dalam strategi marketing mix. "Place Merupakan gabungan antara lokasi dan keputusan atas saluran distribusi dalam hal ini berhubungan dengan bagaimana cara penyampaian produk kepada konsumen dan dimana lokasi yang strategis lokasi berhubungan dengan dimana perusahaan melakukan kegiatan operasional," (Lupiyoadi, 2001, hal. 61). Dalam place ini menurut Lupiyoadi (2001), “Ada tiga jenis interaksi yang dapat digunakan:

1. Konsumen mendatangi perusahaan.

2. Perusahaan mendatangi konsumen.

3. Perusahaan dan konsumen tidak bertemu langsung, “ (hal. 61).

Saluran distribusi (channels) menurut Lupiyoadi (2001), “Terdapat tiga pihak inti dalam saluran distribusi, diantaranya perusahaan, perantara dan konsumen," (hal. 62). Untuk mendapat saluran distribusi yang tepat perusahaan dapat menggunakan jenis distribusi yang dapat digunakan. Menurut Lupiyoadi (2001), "Sarana untuk saluran distribusi yaitu:

1. Direct sales

2. Agent atau broker

3. Agen broker penjual atau pembeli

4. Franchises dan constracted service deliverers," (hal. 62).

\subsubsection{Promotion (Promosi)}

Unsur keempat dari strategi marketing mix yaitu promosi. Menurut Madura (2007), "Promosi adalah tindakan menginformasikan atau mengingatkan pelanggan mengenai suatu produk atau merek tertentu," (hal. 272).

Lupiyoadi (2001) berpendapat Aktivitas periklanan (promosi) dibagi ke beberapa macam jenis periklanan:

1. Advertising (periklanan), iklan merupakan salah satu bentuk dari komunikasi impersonal (impersonal communication) yang digunakan oleh perusahaan.

2. Personal selling, jenis iklan ini terkadang digunakan oleh perusahaan dengan target pemasaran yang sebenarnya bukanlah calon konsumen pembeli, namun target pasar ini adalah calon pembeli potensial.

3. Sales promotion, jenis promosi ini menggunakan jasa sales promosi yang bertugas menyampaikan pesan perusahaan dalam meraih konsumen.

4. Public relation, jenis promosi ini dilakukan melalui kegiatan yang bersifat public.

5. Word of mouth, strategi promosi ini tidaklah secara langsung, namun dilakukan dari customer ke customer lain, customer yang menerima 
Jurnal Ekonomi dan Perbankan Syariah

Vol. 4. No.1, April 2017: 71-94, ISSN (cet): 2355-1755 | ISSN (online): 2579-6437

kepuasan suatu produk akan menceritakan kebagusan produk tersebut kepada yang lain hingga orang yang mendengar kebagusan produk tersebut tertarik dan membeli produk tersebut.

6. Direct marketing, direct marketing ini merupakan jenis promosi langsung, ada beberapa jenis direct marketing:
a. Direct mail
b. Mail order
c. Direct response
d. Direct selling
e. Telemarketing
f. Digital marketing, (hal. 108-111).

\subsection{MUAMALAH DALAM PANDANGAN ISLAM}

Islam merupakan agama yang sempurna, karena Islam adalah agama yang rahmatan lil alamin, rahmat bagi seluruh alam. Setiap seluk beluk kehidupan manusia tak luput dari aturan Islam. Allah SWT berfirman:

Artinya: "..... Pada hari ini orang-orang kafir telah putus asa untuk (mengalahkan) agamamu, sebab itu janganlah kamu takut kepada mereka dan takutlah kepada-Ku. Pada hari ini telah Kusempurnakan untuk kamu agamamu, dan telah $\mathrm{Ku}$-cukupkan kepadamu nikmat-Ku, dan telah $\mathrm{Ku}-$ ridhai Islam itu jadi agama bagimu. Maka barang siapa terpaksa karena kelaparan tanpa sengaja berbuat dosa, sesungguhnya Allah Maha Pengampun lagi Maha Penyayang," (Q.S. Al-maidah: 3).

Dari ayat tersebut dapat kita kita ketahui bahwa Allah telah menyempurnakan ajaran Islam, dan Islam adalah agama sempurna yang mengatur setiap sendi-sendi kehidupan.

Kegiatan Muamalah Merupakan bagian dari aturan hukum Islam. "Hukum muamalah islam bersumber dari Al-Qur'an dan Sunnah, karena keduanya sumber acuan dasar yang ma'shum (terpelihara dari kesalahan) dimana Al-Qur'an pertama dan As-Sunnah sebagai sumber kedua," (Qaradhawi, 2002, hal. 355-356).

Dalam hal muamalah, dibolehkan untuk berijtihad. "Ijtihad di benarkan selama itu untuk kemaslahatan yang tidak bertentangan dengan ketetapan syariat. Ijtihad bisa saja terjadi pada setiap hukum dimana dasarnya berasal dari kebiasaan, tradisi dan kemaslahatan. Jika kemaslahatannya berubah, hukumnya ikut berubah. Hal ini dipengaruhi oleh banyaknya situasi dan kondisi baru yang menuntut ijtihad baru," (Az-Zuhaili, 1993, hal. 220).

Bentuk-bentuk ijtihad diantaranya adalah ijma dan qiyas. Ijma dan qiyas bisa di ambil sebagai hukum. "Meskipun dapat menjadi hukum, validitas otoritas harus ada rekomendasi Al-Qur'an dan As-Sunnah, sehingga validitas hukumnya tidak bisa berdiri sendiri, artinya sumber asal harus dari 
Al-Qur'an dan As-Sunnah," (Qaradhawi, 2002, hal. 356). Serta dalam ijtihad, hanya pada masalah non dasar syariah. "Tidak diperbolehkan dalam prinsipprinsip dasar syariah yang umum dan hukum-hukumnya bersifat pasti," (AzZuhaili, 1993, hal. 221). berikut:

Prinsip-prinsip muamalah menurut Haroen (2007) adalah sebagai

1. Prinsip dasar dalam persoalan muamalah adalah untuk mewujudkan kemaslahatan umat manusia, dengan memperhatikan dan mempetimbangkan berbagai situasi maupun kondisi yang berkaitan dengan manusia itu sendiri.

2. Apapun jenis muamalahnya, hukumnya boleh selama tidak ada dalil yang mengharamkannya, hal ini didasarkan pada kaidah fiqih " $A l$ ashlu fil muamalah al ibahah illa ayyadulla addalilu ala tahrimihi", dengan rincian sebagai berikut:

a. Seluruh tindakan muamalah tersebut tidak terlepas dari nilainilai ketuhanan.

b. Seluruh tindakan muamalah tersebut tidak terlepas dari nilainilai kemanusiaan dan dilakukan dengan mengetengahkan akhlak yang terpuji, sesuai dengan kedudukan manusia sebagai khilafah di muka bumi.

c. Melakukan pertimbangan atas kemaslahatan pribadi dan kemaslahatan masyarakat.

d. Menegakkan prinsip-prinsip persamaan hak dan kewajiban diantara sesama manusia.

e. Segala yang kotor-kotor adalah haram, baik berupa ucapan maupun perbuatan. Seperti penipuan, ihtikar (penimbunan), penipuan dan sebagainya.

f. Seluruh yang baik dihalalkan, (hal. 9-12).

\subsection{PENELITIAN TERDAHULU}

Penelitian terdahulu dari penulisan ini yaitu Jurnal "Strategi Marketing Mix dalam Tinjauan Syariat" yang ditulis oleh Ita Nurcholifah (2014). Di dalam penilaian beliau dijelaskan tentang marketing mix yang sesuai syariah berdasarkan Al-Quran dan Hadits. Selain itu penelitian terdahulu dari penelitian ini yaitu Jurnal "Hukum Dagang dalam Islam" oleh Darmawati (2013), jurnal ini membahas tentang hukum dagang menurut Islam, dalam penelitian ini beliau membahas hukum dagang dari sudut marketing mix. Pada tulisannya marketing mix dikaitkan dengan Al-Quran dan Hadits dan bentuk muamalah terlarang dalam Islam. Perbedaan penelitian penulis dengan penelitian terdahulu yaitu penjelasan marketing mix sesuai dengan syariah lebih rinci, karena penelitian penulis menilai marketing mix berdasarkan Al-Qur'an, Hadits, Ijtihad Ulama, dan penelitian yang berkaitan 
Jurnal Ekonomi dan Perbankan Syariah

Vol. 4. No.1, April 2017: 71-94, ISSN (cet): 2355-1755 | ISSN (online): 2579-6437

| 81

dengan penulisan ini. Selain itu, konsep marketing mix syariah yang dikemukakan penulis disesuaikan dengan kondisi ekonomi modern. Sehingga hasil penelitian penulis bukan hanya sekedar teori, namun juga bisa menjadi masukan dalam menetapkan strategi marketing mix yang sesuai dengan syariah.

\section{METODE PENELITIAN}

Jenis penelitian yang digunakan dalam penelitian ini bersifat deskriptif, sedangkan metode penelitian yang digunakan dalam penelitian ini melalui studi pustaka, baik itu melalui buku, jurnal dan sumber penelitian lainnya yang berhubungan dengan penulisan ini.

\section{PEMBAHASAN}

Marketing mix merupakan bagian dari ilmu marketing, marketing erat kaitannya dengan hubungan sosial. Hubungan sosial dalam islam ada aturannya tersendiri, sehingga dalam penentuan strategi marketing mix oleh marketer muslim tidak lepas dari aturan islam. Marketing mix yang sesuai dengan aturan Islam yaitu sebagai berikut:

\subsection{PRODUCTS (PRODUK)}

Produk dalam Islam mempunyai bahasannya tersendiri, karena produk dalam Islam harus memperhatikan aspek khusus terkait suatu produk.

As-Syaibani berpendapat bahwa dalam Islam ketika dalam pembuatan produk tidak semua dikatakan sebagai aktivitas produksi karena erat kaitan dengan halal dan haram. Sehingga Islam memandang produk harus mempunyai nilai guna dan juga mengandung unsur kemaslahatan didalamnya yang meliputi lima asas pokok kehidupan, yaitu menjaga agama, menjaga jiwa, menjaga akal, menjaga keturunan, serta menjaga harta, (Karim, 2004, hal. 234).

Penetapan strategi produk yang sesuai syariah adalah sebagai berikut:

\section{Produk Mutlak Harus Halal}

Produk yang Islami adalah produk yang telah teruji dan lolos uji kehalalannya menurut syara. Seorang muslim diperintahkan oleh Allah untuk memakan makanan yang halal, Allah Swt berfirman:

Artinya: "Dan makanlah makanan yang halal lagi baik (thayib) dari apa yang telah dirizkikan kepadamu dan bertaqwalah kepada Allah dan kamu beriman kepada-Nya," (Q.S. Al-Maidah: 88).

Tafsir ayat ini menurut Quthb (2004), "Menjelaskan terkait tentang kehalalan, Allah menghalalkan setiap hal yang baik, karena hal-hal yang baik itu sangat diperlukan manusia untuk kemaslahatan dirinya dan kehidupannya, karena hal itu merupakan salah satu fitrah manusia, dan Allah tidak melupakan satupun kebutuhan fitrah manusia, " (Quthb, 2004, hal. 321). 
Dari ayat dan tafsir ayat tersebut kita dapat mengetahui perintah allah sebuah keharusan memakan makanan halal dan baik kepada setiap muslim. Kehalalan produk sangatlah penting untuk setiap muslim, karena kehalalan suatu produk merupakan suatu hal yang mutlak di lakukan dalam setiap menetapkan strategi produk. Saat produk dipasarkan kepada konsumen, kehalalan produk jangan pernah diabaikan, karena untuk kemaslahatan konsumen.

Dalam produk pangan contohnya, tidak terlepas dari batasan halal dan haram. "Pada makanan halal ada batasan tertentu yang ditetapkan, pertama bahan baku harus halal, kedua untuk hewan yang disembelih untuk konsumsi harus diproses secara syar'i, dan ketiga yaitu tidak mencampurkan antara halal dan haram," (Samori, Ishak, \& Kassan, 2014, hal. 483).

Kehalalan suatu produk memiliki spesifikasi yang rinci. "Imam AlGhazali mengemukakan benda-benda dalam perspektif halal dan haram ini diklasifikasikan menjadi dua macam, yaitu haram karena hakekat benda itu sendiri, kedua karena sifat barang (proses atau ciri) itu sendiri," (Sucipto, 2012, hal. 118). Dari pernyataan imam Al-Ghazali tersebut dapat diketahui bahwa produk yang halal dapat dinilai dari dua aspek, yaitu dari aspek dzatnya (aspek inti produk itu sendiri) dan aspek perolehannya atau bisa disebut juga cara prosesnya. Dua aspek ini sangatlah penting untuk diperhatikan dalam Islam.

Aspek pertama yaitu halal menurut dzatnya, atau dari produknya itu sendiri. Salah satu hal yang menjelaskan tentang unsur produk haram menurut dzatnya dalam Al-Qur'an yaitu:

Artinya: "Diharamkan bagimu (memakan) bangkai, darah, daging babi, (daging hewan) yang disembelih atas nama selain Allah, yang tercekik, yang terpukul, yang jatuh, yang ditanduk, dan diterkam binatang buas, kecuali yang sempat kamu menyembelihnya, dan (diharamkan bagimu) yang disembelih untuk berhala. Dan (diharamkan juga) mengundi nasib dengan anak panah, (mengundi nasib dengan anak panah itu) adalah kefasikan...., (Q.S Al-Maidah: 3).

Tafsir ayat ini menurut Quthb (2004), "Berkaitan dengan Objek yang diharamkan Allah, Objek yang diharamkan Allah pada ayat ini karena disebabkan adanya keburukan di dalamnya dan juga menimbulkan kejelekan pada sisi-sisi tertentu dari kehidupan manusia," (hal. 169).

Dari penjelasan ayat tersebut dapat diketahui bahwa setiap yang halal itu baik, sehingga dapat diketahui bahwa dalam Islam, produk mutlak harus halal, karena menyangkut aspek kemaslahatan di dalamnya. Adapun Hadits Nabi yang membahas hal ini, salah satunya yaitu Hadits Nabi yang diriwayatkan oleh Jabir:

Artinya: "Bahwa ia mendengar Rasulullah saw bersabda ketika hari fathu makkah "Allah dan rasulnya telah menyatakan haram penjualan khamar, hewan yang mati alami tidak disembelih, babi dan berhala" Nabi Muhammad juga mengatakan "Harga yang dibayarkan untuk membeli seekor anjing itu haram, sewa yang dibayarkan ke pelacur itu juga haram, dan pendapatan dari cupper itu tidak halal,"(H.R. Muslim). 
Jurnal Ekonomi dan Perbankan Syariah

Vol. 4. No.1, April 2017: 71-94, ISSN (cet): 2355-1755 | ISSN (online): 2579-6437

| 83

Diperkuat dengan Hadits Nabi yang diriwayatkan dari Abu Mas'ud Al-Anshari, Bahwa beliau berkata:

Artinya: "Rasulullah saw melarang uang hasil jual anjing, uang hasil pelacuran dan uang pemanisnya dukun (peramal)," (H.R.Tirmidzi).

Sedangkan halal dari segi cara memperolehnya atau sifatnya, dalam hal produk artinya produk tersebut bukan diperoleh dengan cara yang haram, seperti barang curian, barang selundupan ataupun barang bersifat ilegal.

Rasulullah Saw bersabda:

Artinya: "Siapa saja yang membeli barang curian, sementara ia tahu itu barang curian, maka ia telah berserikat dalam dosa dan aibnya," (H.R. Al-Hakim).

Selain itu juga proses membuat produk juga harus sesuai dengan syariat, seperti dalam produk pangan daging, seperti yang dijelaskan sebelumnya proses penyembelihan hewan untuk pengambilan daging harus sesuai dengan syariat Islam.

\section{Produk Harus Mengandung Kemaslahatan}

Aspek terpenting selanjutnya seperti yang telah dijelaskan sebelumnya mengacu pada pendapat As-syaibani, Produk yang Islam selain bersifat halal, harus mengandung Maslahat dan nilai guna di dalamnya. "Maslahat dan nilai guna yang dikatakan As-Syaibani yaitu terpenuhinya lima unsur pokok yang berkaitan dengan agama (hifdzu ad-din), jiwa (hifdzu an-nafs), akal (hifdzu al-aql), keturunan (hifdzu an-nashl), dan harta (hifdzu al-maal),"“ (Karim, 2004, hal. 320).

Dengan memperhatikan lima unsur pokok tadi, dalam hal produk yang memiliki nilai guna dan maslahat menurut Islam dapat diaplikasikan dalam penerapan strategi bauran produk yang mengandung kemaslahatan melalui pertimbangan aspek berikut:

1. Produk yang dibuat harus mempunyai tujuan manfaat yang jelas bagi konsumen, artinya dalam membuat produk, baik perusahaan maupun penjual harus memiliki tujuan atau manfaat suatu produk bagi konsumen yang dituju.

2. Produk tidak mengandung hal yang membahayakan jiwa konsumen. Maksudnya, produk yang dibuat tidak membuat konsumen ketika menggunakan atau mengkonsumsinya mengalami sesuatu yang tidak diinginkan. Hal ini merupakan cerminan dari aplikasi hifdzu an-nafs (menjaga jiwa).

3. Produk yang dibuat bukan untuk sarana kemaksiatan, produk yang Islami jangan ditujukan untuk kegiatan yang berkaitan dengan maksiat, seperti untuk sarana free sex dan sebagainya. Allah Swt berfirman: 
Artinya: "Dan janganlah kalian mendekati zina; Sesungguhnya zina itu adalah suatu perbuatan yang keji. dan suatu jalan yang buruk," (Q.S. Al-Israa’: 32).

4. Produk yang dibuat bukan sebagai sarana untuk mengekploitasi ketamakan manusia, artinya produk diciptakan bukan bertujuan untuk menciptakan konsumerisme yang berlebihan. Firman Allah SWT:

Artinya: "Dan berikanlah kepada keluarga-keluarga yang dekat akan haknya, kepada orang miskin dan orang yang dalam perjalanan dan janganlah kamu menghambur-hamburkan (hartamu) secara boros. Sesungguhnya pemboros-pemboros itu adalah saudara-saudara syaitan dan syaitan itu adalah sangat ingkar kepada Tuhannya," (Q.S. Al-Isra: 26-27).

\subsection{PRICE (HARGA)}

Dalam setiap keputusan yang diambil seorang marketer Islami harus dilandasi dengan keadilan ekonomi dan kemaslahatan. "Sikap keadilan ekonomi merupakan sikap untuk membuat setiap individu mendapatkan haknya sesuai kontribusi masing-masing kepada masyarakat serta setiap individu harus bebas dari eksploitasi individu lainnya, sehingga Islam mengharamkan segala bentuk hal yang merugikan bagi orang lainnya," (Kartajaya \& Sula, 2006, hal. 14). Hal ini dijelaskan dalam Firman Allah Swt:

Artinya: "Dan janganlah kalian merugikan manusia pada hak-haknya dan janganlah kalian merajalela di muka bumi dengan berbuat kerusakan,"( Q.S. Asy-Syuara: 183).

Pembahasan tentang harga dalam Islam melalui berbagai pendapat syariah dan pendapat para ulama tidak bersifat rinci terkait dengan strategi penentuan harga. Secara umum penentuan harga dalam Islam diserahkan pada mekanisne pasar, hal ini merujuk pada Hadits Rasulullah Saw melalui Anas Bin Malik RA:

Artinya: "Suatu saat di masa Rasulullah Saw harga merangkak naik. Lalu orang-orang mengatakan, "Wahai Rasulullah, tetapkanlah harga untuk kami". Rasulullah bersabda,"Sesungguhnya Allah-lah yang mematok harga, yang menyempitkan dan melapangkan rizki, dan sungguh aku berharap untuk bertemu Allah dalam kondisi tidak ada seorang pun dari kalian yang menuntutku dengan suatu kezaliman, baik dalam darah atau harta," (H.R. At-Tirmidzi dan Abu Daud).

Dalam Islam tidak ada aturan patokan harga yang harus ditetapkan, karena dalam Islam harga itu merupakan sunnatullah, para ulama seperti Ibnu Taymiyah berpendapat bahwa harga terbentuk oleh kekuatan pasar. Menurut Amalia (2010), "Pembahasan harga yang dimaksud Ibnu Taymiyah yakni kompensasi yang adil (iwad al mitsl) dan harga yang adil (tsaman al mitsl). 
Jurnal Ekonomi dan Perbankan Syariah

Vol. 4. No.1, April 2017: 71-94, ISSN (cet): 2355-1755 | ISSN (online): 2579-6437

$\mathbf{8 5}$

Kompensasi yang setara akan diukur dan ditaksir oleh hal-hal setara, dan itulah esensi dari keadilan (nafs al-adl)," (hal. 210).

Strategi penetapan harga Islam membebaskan seseorang menetapkan harga selama itu wajar, adil, adanya suka rela antara pembeli dan penjual serta tidak menimbulkan kedzaliman. Hal ini didasarkan pada Hadits Nabi:

Artinya: "Jual beli itu tidak lain dengan sama-sama rela," (H.R. Ibnu Majah). harga:

Serta diperkuat oleh Hadits Nabi yang lain terkait dengan masalah

Artinya: "Nabi Saw pernah menjual anak panah dan pelana dengan harga yang lebih tinggi," (H.R. Ahmad).

Sah-sah saja seorang pedagang atau perusahaan menetapkan harga, namun Islam melarang penetapan harga yang merugikan orang lain, karena Islam melarang segala bentuk kedzaliman dan mengedepankan kemaslahatan. Dalam penetapan harga Islam mengajarkan beberapa aspek yang harus diperhatikan, diantaranya:

\section{Pengambilan Keuntungan yang Wajar dan Larangan Melakukan Ghabn}

Dalam penetapan harga menurut Islam harus memperhatikan keadilan dan kemaslahatan. "Dalam proses penentuan harga, Islam memandang harga haruslah disesuaikan dengan kondisi barang yang dijual,“ (Darmawati, 2013, hal. 155).

Islam melarang tindakan pengambilan keuntungan yang mengandung unsur gharar di dalamnya dan memerintahkan pengambilan keuntungan yang wajar. adapun bentuk gharar dalam harga yaitu ghabn. "Ghabn adalah membeli sesuatu dengan harga yang lebih tinggi dari harga rata-rata pasar pada umumnya, atau membeli sesuatu dengan harga lebih rendah dari harga rata-rata pasaran. Ghabn dilarang dalam Islam karena mengandung unsur penipuan dalam harga yang bisa merugikan orang lain," (An-Nabhani, 2009, hal. 203).

Ghabn ini dilarang dalam penetapan harga perusahaan, karena merugikan konsumen. Ghabn biasanya terjadi karena ketidak tahuan konsumen pada harga atau motif dari perusahaan yang ingin untung besar. Terkait dengan tindakan ghabn ini di masa modern ini terkadang masih terjadi, fenomena dimasyarakat dikenal dengan getok harga, yaitu penetapan harga yang tidak masuk akal dan diatas harga pasar. Sebagai contoh penetapan harga yang tidak benar dan merugikan masyarakat adalah sebagai berikut:

Seorang pengguna Facebook mengunggah sebuah bon atau kwitansi pembayaran makanan yang diakuinya berada di sebuah restoran di Anyer. Di kwitansi tersebut ada tujuh menu makanan dan minuman yang dipesan. Namun, harga tiap makanan terbilang mahal. Dua ikan bakar dihargai Rp 400.000, 1 cumi saos tiram Rp 180.000, 3 cah kangkung Rp 200.000, 1 baso sapi Rp 20.000, 2 nasi putih Rp 
90.000, 2 lalap dan sambal $\mathrm{Rp} 30.000$, dan 1 es teh manis $\mathrm{Rp}$ 80.000. Sehingga jumlah total yang harus dibayar oleh pemesan adalah Rp 1.000.000, (Merdeka, 2014).

Namun, ghabn yang dilarang dalam Islam adalah ghabn fahisy (ghabn dalam jumlah besar), sedangkan ghabn dalam jumlah kecil diperbolehkan dalam islam, (Karim, 2007, Hal.153).

Terkait dengan meraih keuntungan yang lebih dari konsumen sebaiknya mengambil keuntungan yang tidak tinggi. "Imam Al-Ghazali mengajarkan untuk mengambil keuntungan yang sedikit meskipun tingkat keuntungan tidak memiliki batasan tertinggi. Menurut Imam Al-Ghazali 'Barang siapa puas dengan tingkat laba yang kecil, maka muamalahnya akan berkembang banyak (banyak pelanggannya) dan pada gilirannya akan mendapat untung yang banyak pula,' " (Bashri, 2007, hal. 131).

Menurut Bashri (2007), "Teori untung sedikit dan konsumen banyak merupakan terobosan ilmiah dalam literatur mikro ekonomi," (hal. 131). Selain mengambil keuntungan sedikit dan konsumen yang diajarkan oleh Imam Al-Ghazali. Penetapan harga kepada konsumen juga bisa mencontoh Rasulullah dalam berdagang. "Nabi Muhammad SAW dalam melakukan perniagaan, yakni dengan cara menyebut berapa harga beli barang dari Makkah, biaya transport dari Makkah ke pasar dan lamanya memerlukan waktu sekian hari. Nabi Muhammad menyerahkan pembeli untuk menentukan harga yang pantas terhadap barang yang di jualnya," (Amrin, 2007, hal. 61).

\section{Larangan Persaingan dalam Harga antara Sesama Penjual}

Dalam penetapan harga haruslah memperhatikan kemaslahatan, artinya strategi harga yang diterapkan tidak mengandung mudharat pada pedagang lainnya atau terjadinya persaingan harga tidak sehat antar penjual. Berkaitan dengan persaingan, kemaslahatan dalam penentuan harga harus diperhatikan. "Bila ingin memenangkan persaingan, harga produk harus kompetitif, dalam hal tersebut tidak diperbolehkan membanting harga dengan tujuan menjatuhkan pesaing," (Yusanto \& Widjajakusuma, 2002, hal. 96).

Terkait dengan perang harga, Rasulullah saw bersabda lewat riwayat dari Abdullah bin Umar:

Artinya: "Janganlah kamu menjual menyaingi penjualan saudaramu," (H.R. Bukhari).

Hadits ini menurut Gunara \& Sudibyo (2007), "Merupakan ketegasan larangan Rasulullah Saw pada persaingan yang tidak sehat terutama dalam harga. Perang harga dilarang dalam Islam karena bisa menjadi bumerang bagi para penjual. Secara tidak langsung Rasulullah saw menyuruh kepada setiap muslim agar tidak bersaing dalam harga, tetapi bersaing dalam hal lain seperti kualitas, layanan, dan nilai tambah produk. Hal ini di dasarkan pada Hadits Rasulullah tentang larangan penetapan harga komoditi," (hal. 62-63). 
Jurnal Ekonomi dan Perbankan Syariah

Vol. 4. No.1, April 2017: 71-94, ISSN (cet): 2355-1755 | ISSN (online): 2579-6437

187

4.3 PLACE (PENEMPATAN)

Terkait dengan place, Islam menilai tentang place yang benar harus memperhatikan etika dan juga menghindari bentuk kedzaliman. Hal-hal yang harus diperhatikan adalah sebagai berikut:

\section{Pemilihan Lokasi Usaha yang Strategis}

Islam mengajarkan dalam hal place untuk memilih lokasi yang strategis, seorang marketer ataupun pedagang harus bisa menguasai informasi pasar agar bisa memilih place yang tepat.

Dalam satu riwayat Imam Ahmad diceritakan bahwa beliau pernah menerima utusan dari salah satu kabilah di Bahrain. Rasulullah menanyakan siapa pemimpinnya dan dijawab bahwa pemimpinnya adalah Al-Ashajj. Setelah bertemu dengan Al-Ashajj, beliau bertanya kepada Al-Ashajj berbagai hal dan orang-orang yang terkemuka serta kota-kota perdagangan di Bahrain seperti kota safa, mushaqqar, dan hijar. Pemimpin kabilah tersebut sangat terkejut dengan luasnya wawasan geografis dan sentra-sentra komersial Rasulullah saw. Hingga Al-Ashajj berkata "Sungguh, anda lebih tahu tentang negeri saya daripafa saya sendiri. Anda juga lebih banyak mengenal kota-kota di negeri saya daripada yang saya ketahui". Rasulullah saw menjawab " Saya telah mendapat kesempatan untuk menjelajahi negeri anda dan saya telah diperlakukan dengan baik,"(Antonio, 2009, hal. 86-87).

Dari penjelasan satu riwayat di atas dapat kita ketahui salah satu kesuksesan Nabi dalam berdagang salah satunya adalah dari segi place yaitu penguasaan informasi pasar. Informasi pasar sangatlah penting dalam menentukan lokasi perusahaan yang tepat.

Penentuan lokasi usaha yang strategis dalam islam haruslah memperhatikan aspek kemaslahatan Menurut Yusanto \& Widjajakusuma (2002) , "Lokasi usaha harus baik, sehat, bersih dan nyaman. Harus juga dihindarkan untuk melengkapi tempat usaha yang diharamkan untuk menarik pembeli," (hal. 96). Selain itu dalam pemilihan lokasi usaha harus memperhatikan kemaslahatan. Nurcholifah (2014) berpendapat, "Lokasi usaha bisa dimana saja asalkan tempat tersebut bukan tempat yang dipersengketaan keadaannya," (hal. 82). Dari beberapa pernyataan diatas dapat disimpulkan pemilihan lokasi usaha yang strategis sesuai dengan aturan islam yaitu:

1. Memperhatikan aspek kemaslahatan dan menghindari unsur kedzaliman.

2. Lokasi usaha yang layak dan tidak mengganggu masyarakat sekitar.

3. Perlunya informasi pasar untuk menentukan lokasi yang strategis.

2. Kebolehan Penggunaan Samsarah (Perantara)

Selain dalam hal lokasi usaha, hal yang perlu diperhatikan adalah saluran distribusi. Islam membolehkan praktek samsarah, samsarah bisa diartikan sebagai makelar (agen). "Pelaku samsarah adalah simsar, simsar adalah 
sebutan bagi orang yang bekerja untuk orang lain dengan upah, baik untuk keperluan menjual maupun membelikan. Hal ini termasuk pekerjaan yang diperbolehkan syara," (An-Nabhani, 2009, hal. 178). Dalil diperbolehkannya samsarah adalah sebagai berikut :

Artinya: "Dari 'Urwah al-Bariqi bahwa Nabi SAW memberinya satu dinar untuk dibelikan seekor kambing. Maka dibelikannya dua ekor kambing dengan uang satu dinar tersebut, kemudian dijualnya yang seekor dengan harga satu dinar. Setelah itu ia datang kepada Nabi SAW dengan seekor kambing. Kemudian beliau SAW mendoakan semoga jual belinya mendapat berkah. Dan seandainya uang itu dibelikan tanah, niscaya mendapat keuntungan pula," (H.R. Ahmad dan At-Tirmidzi).

Dari hadits tersebut kita mengetahui bahwa samsarah di bolehkan dalam Islam, karena Nabi sendiri pernah melakukannya. "Dalam kegiatan samsarah ini memiliki batasan yang harus diperhatikan, pertama kerja yang dikontrak untuk keperluan menjual maupun membelikan harus sama-sama diketahui kerjanya, kedua pelaku samsarah haram mengambil keuntungan dari pembelian atau penjualan, karena keuntungan tersebut merupakan hak orang yang mengutusnya, kecuali kalau orang yang bersangkutan diberi izin oleh orang yang mengutusnya maka baru diperbolehkan,"(An-Nabhani, 2009, hal. 78-79).

Dari penjelasan tersebut dapat diketahui bahwa samsarah boleh selama tidak melanggar ketentuan-ketentuan syariat.

\section{Larangan Ihtikar}

Dalam kegiatan perekonomian seringkali ditemukan tindakan penimbunan barang, penimbunan ini dalam Islam disebut dengan ihtikar. Ihtikar seringkali terjadi di perekonomian modern, seperti kasus contoh berikut:

Ketua Kamar Dagang dan Industri (Kadin) Kepri, Makruf Maulana, mengatakan kelangkaan dan mahalnya harga beras di Batam diduga karena permainan para kartel atau kelompok usaha yang ingin mengendalikan harga komoditas tersebut. Tujuannya, mengeruk untung berlipat saat harga kebutuhan pokok itu meroket."Ini jelas dikendalikan oleh kartel-kartel tertentu," ujar Makruf, Rabu (21/10). Menurut Makruf, kecurigaan itu berdasar. Pasalnya, beberapa waktu lalu pihaknya mengaku mendapat laporan stok beras di Batam untuk beberapa bulan ke depan masih cukup, (Batam pos, 2015).

Dari contoh kasus tersebut, penimbunan terkadang terjadi dan dilakukan oleh orang-orang tertentu, motifnya yaitu untuk meraih keuntungan lebih. "Islam melarang kegiatan ihtikar (penimbunan), karena penimbunan secara mutlak dilarang, sehingga hukumnya haram. Hal ini dilarang," (An-Nabhani, 2009, hal. 208). An-Nabhani memperkuat alasannya berdasarkan hadits yang diriwayatkan oleh Imam Muslim dalam shahih muslimnya dari Said bin Al Musaib dari Ma'mar bin Abdullah Al-Adawi, bahwa Nabi Saw bersabda: 
Jurnal Ekonomi dan Perbankan Syariah

Vol. 4. No.1, April 2017: 71-94, ISSN (cet): 2355-1755 | ISSN (online): 2579-6437

$\mathbf{8 9}$

Artinya: "Tidak akan melakukan penimbunan selain orang yang salah, ”(H.R. Muslim).

Lalu diperkuat dengan hadits nabi yang lain:

Artinya: "Rasulullah saw melarang menimbun dalam hal makanan," (H.R. Al-Baihaqi).

Larangan hadits tersebut menurut An-Nabhani (2009), "Menunjukkan adanya tuntutan untuk meninggalkan. Sementara cercaan bagi orang yang melakukan penimbunan disebut dengan khati yang berarti orang berdosa dan berbuat maksiat, hal ini mengindikasikan tuntutan meninggalkan tersebut bermakna tegas (jazm)," (hal. 209).

Menurut As-Sabatin (2009), "Penyebutan kata makanan di dalam hadits tersebut dan semisalnya tidak menjadikan khusus untuk makanan, dengan kata lain, penyebutan kata makanan pada sebagian riwayat hadits tentang penimbunan (ihtikar) merupakan tanshish (pelafalan) terhadap satu jenis dari jenis-jenis penimbunan sebagai contoh atasnya, bukan sebagai batasan bagi penimbunan juga bukan merupakam sifat yang bisa ditarik konotasinya," (hal. 291-292).

Sehingga dapat disimpulkan bahwa tindakan ihtikar (penimbunan) adalah dosa. Penimbunan ini dimaksudkan untuk mengumpulkan barangbarang disuatu tempat dengan maksud meraih keuntungan lebih. Sehingga ketika harga barang tinggi, maka ketika barang tersebut dijual penimbun mendapat keuntungan yang besar.

Adapun yang termasuk tindakan penimbunan ini menurut An-Nabhani (2009), "Penimbunannya sampai pada suatu batas yang menyulitkan warga setempat untuk membeli barang yang tertimbun, dan juga mengumpulkan barang dengan menunggu naiknya harga sehingga bisa menjualnya dengan harga mahal. Hadits yang diriwayatkan Nabi saw termasuk pada penimbunan barang secara umum yang dibutuhkan oleh masyarakat umum," (hal. 209).

Dari penjelasan diatas dapat diketahui bahwa ihtikar dilarang dalam hal bahan pokok dan barang dibutuhkan oleh manusia secara umum. Dalam konteks modern, ihtikar bisa berlaku bukan sekedar bahan makanan pokok, tapi juga bisa di samakan dengan hal lainnya yang menjadi hajat kehidupan umum manusia. Sehingga makanan pokok bisa di qiyaskan dengan hal lainnya karena sebabnya yang sama yaitu kebutuhan khalayak umum.

Ihtikar jika di lihat dalam segi place ini menghambat dalam pendistribusian barang kepada konsumen. Maka jelaslah bahwa ihtikar merupakan suatu hal kedzaliman yang harus ditinggalkan.

\subsection{PROMOTION (PROMOSI)}

Dalam hal muamalah, Islam membebaskan setiap muslim untuk melakukan muamalah selama tidak dilarang oleh syariat. Dalam hal promosi Islam membebaskan segala jenis promosi asalkan sesuai dengan tuntunan Islam. Promosi yang sesuai dengan syariat adalah sebagai berikut:

1. Mengedepankan Prinsip Akhlak 
Promosi merupakan sarana perusahaan untuk menjual produknya kepada konsumen melalui komunikasi. Kegiatan komunikasi erat kaitannya dengan hubungan sosial, Islam telah mengajarkan lewat Al-Qur'an dan Hadits tentang hubungan sosial yang baik. Hal yang utama dan harus diperhatikan dalam promosi adalah akhlak, karena seringkali cara pemasaran kapitalis sering mengabaikan akhlak dalam penjualannya. Ketika perusahaan memasarkan produknya kepada konsumen, disanalah sifat perusahaan akan tertampakkan ke publik. Sebuah perusahaan Islami harus mencontoh perdagangan yang dijalankan oleh Rasulullah saw, sehingga perusahaan lebih mengedepankan akhlak pemasaran produk ketimbang memaksimalkan profit dengan menghalalkan berbagai cara, karena seringkali iklan modern mengabaikan prinsip etika (akhlak) didalamnya. Contoh kasus iklan yang mengabaikan etika dikemukakan oleh Adona dalam Jurnal "Etika Bisnis Periklanan: Pelanggaran Pedoman Etis Iklan Televisi 2012" yaitu:

Pada 28 Desember 2011 badan regulator Komisi Penyiaran Indonesia (KPI) menegur semua stasiun televisi untuk memperbaiki adegan dalam tayangan iklan "Mie Sedaap". Iklan tersebut menayangkan adegan seorang guru yang memegang sebuah produk mie dan di kepalanya bertengger seekor ayam. Menurut KPI, tayangan iklan tersebut tidak memperhatikan norma dan nilai yang berlaku dalam lingkungan sekolah, memperolok tenaga pendidik (guru) dan merendahkan sekolah sebagai lembaga pendidikan, (Adona, 2012, hal. 46).

Contoh iklan yang ditegur KPI diatas merupakan contoh iklan yang mengabaikan etika (akhlak). Terkait dengan promosi, seorang marketer muslim harus mencontoh perdagangan Nabi, karena menurut Kertajaya \& Sula (2006), "Nabi Muhammad mengajarkan cara yang benar-benar menjual (promosi)," (hal. 55). Nabi Saw bersabda:

Artinya: "Hindarilah banyak bersumpah ketika melakukan transaksi bisnis, sebab dapat menghasilkan sesuatu penjualan yang cepat tapi menghapus berkah," (H.R. Al-Bukhari dan Muslim).

Dalam hadits Nabi yang lain, orang yang melakukan sumpah palsu tidak akan diajak bicara oleh Allah SWT di akhirat nanti. Nabi Saw bersabda, Artinya: "Ada tiga (gologan) yang tidak diajak bicara oleh Allah pada hari kiamat; orang yang suka mengugkit-ungkit pemberian dimana dia tidak pernah memberikan sesuatu kecuali akan dibahas, orang yang menjadikan laris barang dagangannnya dengan sumpah palsu, dan orang yang mengisbaalkan sarungnya” (H.R. Muslim)

Seringkali dalam kegiatan penjualan yang menggunakan sumpah atau promosi yang berlebihan dilakukan karena untuk meyakinkan pembeli, hal ini terjadi karena ketidak percayaan pada produknya sendiri, atau tidak yakin bisa memberikan pelayanan yang baik dan cenderung berlebihan dalam beriklan, sehingga profesionalismenya terlihat begitu rendah, dan juga praktik sumpah ini sebaiknya dihindari menurut syariah.

Sehingga penerapan promosi yang sesuai dengan syariat jangan dilupakan. "Kegiatan Promosi yang sesuai syariat yaitu kejujuran, 
Jurnal Ekonomi dan Perbankan Syariah

Vol. 4. No.1, April 2017: 71-94, ISSN (cet): 2355-1755 | ISSN (online): 2579-6437

| 91

menghindari penjelasan produk yang salah, tidak mencampurkan dengan barang-barang haram dan tidak menggunakan perempuan sebagai model iklan," (Islam \& Alam, 2013, hal. 115). Penggunaan model perempuan dilarang karena menampilkan kecantikan dan penampilan unsur seksualitas dan pornografi di dalamnya.

\section{Larangan Melakukan Tadlis (Penipuan)}

Lawan dari kejujuran adalah bohong, kebohongan merupakan sifat tercela yang harus dihindari oleh setiap muslim. "Islam mempunyai aturan tersendiri tentang mengembangkan harta, Islam melarang segala bentuk muamalah yang tidak transparan dan penuh kebohongan, diantaranya yaitu tadlis (penipuan), tadlis dilarang dalam Islam karena bisa menimbulkan kemudharatan dan juga kedzhaliman baik bagi penjual maupun pihak pembeli," (An-Nabhani, 2009, hal. 206). Seperti di pihak penjual ketika menawarkan suatu barang kepada pembeli, pedagang tersebut mengatakan bahwa barang tersebut bagus tiada kecacatan padahal sebenarnya barang tersebut ada cacatnya dan pembeli akhirnya membeli barang tersebut karena terbujuk oleh si pedagang. Ketika saat pembeli mengetahui barang itu memiliki kecacatan, maka pembelilah yang dirugikan. Bentuk penipuan bukan hanya sekedar menyembunyikan kecacatan, tapi juga promosi yang melebih-lebihkan suatu produk tanpa sebanding dengan kualitas produknya juga merupakan bentuk tadlis (penipuan).

Bashri (2007) mengemukakan bahwa menurut Imam Al-Ghazali iklan komersial harus memperhatikan hal berikut:

1. Dalam menjelaskan barang produsen tidak boleh berbohong. Jika ini dilakukan maka mereka berdosa dan telah berbuat zalim kepada konsumen.

2. Tidak boleh menyembunyikan kekurangannya. jika ini dilakukan, maka prosuden telah sengaja menipu konsumen (taghrir).

3. Menjelaskan kegunaan suatu produk/barang yang sudah biasa dikenal oleh masyarakat secara berlebihan tidak diperbolehkan.

4. Tetapi menjelaskan kegunaan suatu barang yang memuat informasi penting bagi konsumen tanpa berlebihan tidak apa-apa. bahkan dalam keadaan tertentu hal ini sangat diperlukan, (hal. 138-139).

Transparansi dalam melakukan promosi yang Islami sangatlah perlu diperhatikan, karena berkaitan dengan kemaslahatan dalam transaksi jual beli dan tidak melakukan hal curang, dalam satu hadits Nabi yang menyatakan tentang transparansi promosi adalah sebagai berikut:

Artinya: "Rasulullah melewati tumpukan makanan (yang dijual) lalu beliau masukkan tangannya ke dalamnya maka mendapati tangan beliau basah. Maka beliau mengatakan: "Ada apa ini wahai pemilik makanan ini?" "Terkena hujan, ya Rasulullah,” jawabnya. Beliau mengatakan:

"Tidakkah engkau letakkan di bagian atas makanan itu supaya orang 
melihatnya? Orang yang menipu bukan dari golongan kami," (H.R. Muslim, Abu Dawud, At-Tirmidzi, Ibnu Majah, dan Ath-Thabarani).

Dari hadits Nabi diatas, transparansi dalam menjual barang atau promosi wajib dilakukan, hal ini agar terhindar dari segala bentuk penipuan yang bisa merugikan pihak lain dan pihak yang melakukan penipuan bukanlah tergolong umat Nabi Muhammad saw. Promosi haruslah terhindari dari segala tindak penipuan. Menurut Chairiawaty (2012), "Dalam penyampaian promosi atau iklan ada aspek yang perlu diperhatikan:

1. Keikhlasan.

2. Tha'ah.

3. Uswah.

4. Kejujuran (shiddiq).

5. Persaudaraan (Ukhuwah).

6. Edukatif (Tarbawy).

7. Rendah Hati (Tawadhu)," (hal. 161-162).

Maka sudah selayaknya seorang marketer muslim lebih mengedepankan akhlaknya sebagai seorang pemasar ataupun penjual dan menghindari segala bentuk penipuan dalam promosi pemasarannya.

\section{SIMPULAN}

Dari penjelasan di pembahasan sebelumnya dapat disimpulkan bahwa konsep marketing mix yang sesuai dengan syariah adalah pertama, Segi Product (Produk), yaitu (a) Produk mutlak harus halal, halal yang dimaksud yaitu halal dari segi dzatnya maupun dari segi sifatnya; dan (b) Produk harus mengandung kemaslahatan, maksudnya produk yang dibuat harus memiliki nilai manfaat dan tidak bertentangan dengan maqashid syariah. Kedua, Segi Price (Harga), yaitu (a) Penetapan harga yang wajar dan larangan ghabn, maksudnya harga yang ditetapkan haruslah sesuai dengan keadaan pasar dan tidakboleh berlaku semena-mena terhadap harga; dan (b) Larangan persaingan harga antar penjual, maksudnya penjual tidak boleh bersaing dalam harga, tapi dalam hal lain selain harga diperbolehkan.

Ketiga, Segi Place (Penempatan), yaitu (a) Pemilihan lokasi yang strategis, maksudnya Islam mengajarkan pemilihan lokasi usaha yang strategis namun tetap harus memperhatikan aspek kemaslahatan didalamnya; (b) Kebolehan penggunaan samsarah, samsarah adalah nama lain dari broker (perantara/agen). Islam membolehkan samsarah selama objeknya jelas dan pelakuk samsarah tidak mengambil keuntungan kecuali atas izin yang mengutusnya; dan (c) Larangan ihtikar (penimbunan), namun ihtikar yang dilarang dalam islam adalah barang bahan pokok atau barang yang dibutuhkan orang banyak. Keempat, Segi Promotion (Promosi), yaitu (a) Mengedepankan prinsip akhlak, maksudnya dalam kegiatan promosi erat kaitannya dengan hubungan sosial, hubungan sosial ini haruslah dilandasi 
Jurnal Ekonomi dan Perbankan Syariah

Vol. 4. No.1, April 2017: 71-94, ISSN (cet): 2355-1755 | ISSN (online): 2579-6437

| 93

dengan akhlak, (b) Larangan melakukan tadlis (penipuan), penipuan ini

dilarang karena dapat merugikan orang lain.

6. DAFTAR PUSTAKA

Departemen Agama RI. (2004). Al-Qur'an dan Terjemahnya. Bandung: CV Penerbit J-Art.

Al-Albani, M. N. (2004). Shahih Sunan Tirmidzi Buku Satu. Jakarta: Pustaka Azzam.

An-Nawawi, I. (2002). Terjemah Syarah Shahih Muslim Buku Satu. Jakarta: Mustaqiim

Amalia, D. (2010). Sejarah Pemikiran Ekonomi Islam. Depok: Gramata Publishing.

Amrin, A. (2007). Strategi Pemasaran Asuransi Syariah. Jakarta: PT Grasindo.

An-Nabhani, T. (2009). Membangun Sistem Ekonomi Alternatif Persfektif Islam. Surabaya: Risalah Gusti.

Antonio, S. (2009). Muhammad Super Leader Super Manager. Jakarta: Pro LM Centre \& Tazkia Publishing.

As-Sabatin, Y. (2009). Bisnis Islami dan Kritik Bisnis Ala Kapitalis. Bogor: Al-Azhar Press.

Az-Zuhaili, W. (1993). Al-Quran Menjawab Tantangan Zaman. Jakarta: Mustaqim.

Bashri, I. A. (2007). Menguak Pemikiran Ekonomi Ulama Klasik. Solo: Aqwam.

Gunara, T., \& Sudibyo, U. H. (2007). Marketing Muhammad. Bandung: Madani Prima.

Haroen, N. (2007). Fiqih Muamalah. Jakarta: Gaya media pratama.

Karim, A. (2007). Ekonomi Mikro Islami Edisi Ketiga. Jakarta: Grafindo.

Karim, A. (2004). Sejarah Pemikiran Ekonomi Islam. Jakarta: Grafindo.

Kartajaya, H., \& Sula, M. S. (2006). Marketing Syariah. Bandung: Mizan.

Kotler, P., \& Amstrong, G. (1997). Dasar-Dasar Pemasaran Edisi Indonesia Jilid Satu. Jakarta: PT Prehallindo.

Kotler, P., \& Keller, K. L. (2009). Manajemen Pemasaran: Edisi ke 13. Jakarta: Erlangga.

Kotler, P., Kartajaya, H., \& Setiawan, I. (2010). Marketing 3.0. Jakarta: Gramedia Pustaka. 
Lupiyoadi, R. (2001). Manajemen Pemasaran Jasa. Jakarta: Salemba Empat.

Madura, J. (2007). Pengantar Bisnis Edisi Keempat Jilid 2. Jakarta: PT Salemba Empat.

Qaradhawi, Y. (2002). Pengantar Kajian Islam. Jakarta: Pustaka Al Kautsar.

Quthb, S. (2004). Tafsir Fi Zhilalil Qur'an Jilid 3. Jakarta: Gema Insani.

Stanton, W. (1991). Prinsip Pemasaran. Jakarta: Erlangga.

Tjiptono, F. (2004). Pemasaran Jasa . Malang: Bayumedia Publishing.

Yusanto, M. I., \& Widjajakusuma, M. K. (2002). Menggagas Bisnis Islami. Jakarta: Gema Insani Press.

Adona, F. (2012). Etika Bisnis Periklanan: Pelanggaran Pedoman Etis Iklan Televisi 2012. Jurnal Polibisnis, 4(2), 44-62.

Chairiawaty. (2012). Branding Identity Sebuah Tinjauan Mengenai Etika Bisnis Islam. Jurnal Ilmu Komunikasi, 151-166.

Darmawati. (2013). Hukum Dagang Islam. Jurnal Al-Risalah, 13(1), 147162.

Islam, D. E., \& Alam, M. Z. (2013). Advertising an Islamic Perspective. International Journal Of ethics in social sciences, 105-116.

Nurcholifah, I. (2014). Strategi Marketing Mix dalam Perspektif Syariah. Jurnal Khatulistiwa-journal of islamic studies, 4(1), 73-86.

Samori, Z., Ishak, A. H., \& Kassan, N. H. (2014). Understanding the Development of Halal Food Standard Suggestion for Future Research. international journal of science and humanity, 4(6), 482-486.

Sucipto. (2012). Halal dan Haram Menurut Al-Ghazali dalam Kitab Mau'idotul Mukminin. Jurnal Asas, 4(1), 116-127.

Ar. (2015). Beras langka dan mahal di Batam, Kadin tuding disebabkan ulah kartel. Dipetik November 14, 2015, dari http://batampos.co.id/22-102015/beras-langka-dan-mahal-di-batam-kadin-tuding-disebabkanulah-kartel/.

Mardani. (2014). Peristiwa heboh makan di anyer sampai habis Rp 1 juta. Dipetik November 14, 2015, dari http://www.merdeka.com/peristiwa/heboh-makan-di-anyer-sampaihabis-rp-1-juta.html.

Setiawan, O. (2015). Keamanan Pangan. Dipetik Desember 5, 2015, http://www.republika.co.id/berita/koran/opinikoran/15/04/08/nmh7fq7-keamanan-pangan. 